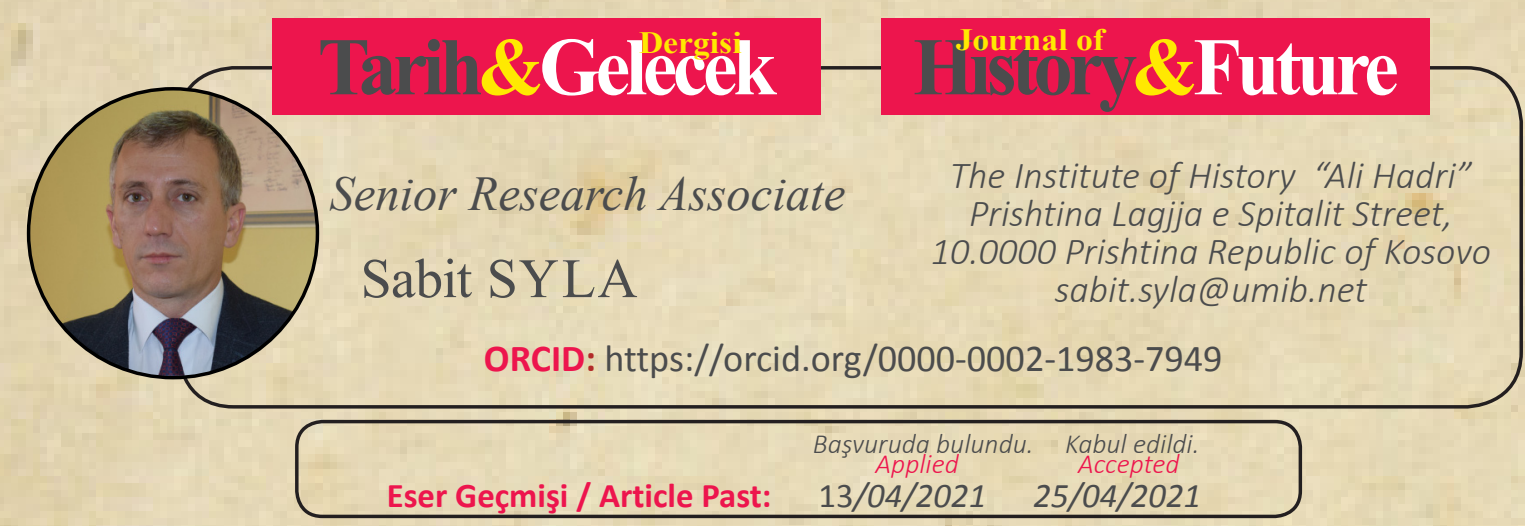

DOI: http://dx.doi.org/10.21551/jhf.915419

Orjinal Makale / Orginal Paper

\title{
The Stance of the International Community towards the Kosovo Issue during the 90's of the Twentieth Century
}

\author{
XX. Yüzyılın 90’’ı Yıllarında Uluslararası Güçlerin Kosova \\ Sorununa Karşı Tutumu
}

\begin{abstract}
The beginning of the year 1990 marked a decisive moment in the history of the Eastern Europe in general, and those of Balkans in particular. The fall of communism and installation of the democracy, although very fragile at first, renewed the unsolved ethnic issues that had been covered up by the communist ideology. Nations, who along the decades lived under the hegemony of bigger nations within a common state, begun to project their future, which they conceived as an ethnic state managed by people themselves. But, what was the standpoint of the international community towards the Kosovo Albanian claims? The paper "The stance of the international community towards the Kosovo issue during the 90's of the twentieth century" aims to elaborate following points: the handling of the Kosovo issue by the international community; the standpoint of the international community towards the claims of Kosovo Albanians for national liberation over the years; the policy of Yugoslavia/Serbia over the Kosovo and international community; the divergences within the international community regarding the Kosovo issue.
\end{abstract}

Key words: Kosovo, Serbia, independence, resistance, international community, etc.

\section{$\ddot{O} z$}

1990'ların başları, genel olarak Doğu Avrupa halklarının ve özel olarak da Balkanlar'ın tarihinde bir dönüm noktası oldu. Komünizmin çöküşü ve demokrasinin yerleştirilmesi, ilk bakışta kırılgan olsa da, komünist ideolojinin örttüğü çözülmemiş etnik sorunların orataya çıkmasına neden oldu. On 
yıllar boyunca ortak bir devletteki en büyük halkların hegemonyası altında yaşayan halklar, bizzat kendileri tarafindan yönetilen bir etnik devlet olarak gördükleri için geleceklerini projelendirmeye başladılar. Peki, uluslararası güçlerin Kosova'nın Arnavut taleplerine karşı tutumu nasıldı? Bu nedenle, "XX yüzyılın 90'larında Kosova sorununa yönelik uluslararası faktörün tutumu” başlıklı makale, Kosova meselesinin uluslararası örneklerde ele alınışını, uluslararası siyasi faktörün Arnavutların taleplerine karşı tutumunu bu makalede açıklanmaya çalışılmıştır. Ayrıca Belgrad'ın Kosova'ya ve uluslararası ülkelere karşı olan tutumunu ele almaya çalışmıştır.

Anahtar Kelimeler: Kosova, Strbistan, bağımsızlık, direniş, uluslararası toplum vb.

\section{Introduction:}

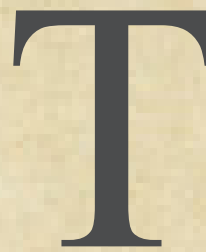

he beginning of 1980s marked a decisive moment to Yugoslavia. The severe economic crisis that had started to crush the Yugoslav economy, accompanied with a trade deficit and deteriorating external debt up to $\$ 15$ billion in 1980 and $20 \%$ of inflation, ${ }^{1}$ was also marked by two major events that would provide a different direction to the political developments in Yugoslavia. The death of Josip Broz in 1980 and the Kosovo Albanian student demonstration of 1981 impacted the awakening and emergence of Serbian nationalism, which latently, though powerless, had resisted as much as it could the decentralization reforms in Yugoslavia since the 1965. An increasingly powerful propaganda begun within the Serbian intellectual, cultural and religious circles, which emphasized the injustice done to the Serbian people since the end of the World War II. Numerous explanations about the suffering ${ }^{2}$ of Serbs and the manners to correct the causes were clearly articulated in the 1986 "Memorandum" of the Serbian Academy of Sciences and Arts. In fact, the main core of the "Memorandum" relied on the decentralization and constitutional arrangement ${ }^{3}$ of Yugoslavia, particularly of Serbia in report to autonomous provinces, which were considered as the origin of subsequent problems. In the first case, that of the decentralization, the Serbian circles were concerned about the division of Serbian people in several states in case of dissolution of Yugoslavia, opening thus the "Serbian issue"; in second case, it was estimated that the Constitution of 1974 provided several state elements to Kosovo, as: the right to approve and to change the Constitution, the right to organize an autonomous governance, the independent judicial system, ${ }^{4}$ etc., raising thus doubts about a possible secession of Kosovo from Serbia.

1 Viktor Meier, Fundi i Jugosllavisë (Lubjanë: Liria, 2007), 25.

2 Sonja Biserko, Kovanje antijugoslovenske zavere, vol. Vol. 1 (Beograd: Helsinksi odbor za ljudska prava u Srbiji, 2006), 104 (The Appeal of 21 Serbian Priests addressed to higher federal and republican organs, in April 1982, embraced "the raise of voice on protection of biological and spiritual being of Serbs in Kosovo and Metohija"); Veljko Vujačić, "Serbian Nationalism, Slobodan Milosević and the Origins of the Yugoslav War," The Harriman Review, Vol. 8, no. 4 (1995): 4. (The book "Knjiga o Milutinu" - Danko Popović, articles of Vuk Drašković about the "genocide" that Croats did against Serbs during the Word War II, and "Grešnik" e "Otpadnik" of Dobrica Ćosić, had an powerful political impact on Serbian mases)

3 Kosta Mihailović and Vasilije Krstić, Memorandum of the Serbian Academy of Sciences and Arts Answers to Criticism (Belgrade: Serbian Academy of Sciences and Arts, 1995), 96-97.

4 Kosovo: pravo i politika, Kosovo u normativnim aktima pre i posle 1974. godine (Beograd: Helsinki odbor za ljudska prava u Srbiji, 1998), 12. 
Thus, the main task of the Serbian political class was to abolish the autonomy of the provinces, respectively to reduce their executive and legislative powers. Accomplishment of such a task would take on a more determined character after the rise of Slobodan Milosevic on the head of the Central Committee of Communist League of Serbia in 1987. Milosevic was a Serbian communist politician who had the courage to abuse the feelings of discontent among Serbs by drafting a political strategy on Kosovo, based on what was perceived as the national interest of Serbs. He provided a simple justification: if Serbia fails to regain control over Kosovo, then this will be the end of Serbian nation. Years later it became clear that Kosovo had been the initial point of a nationalist and expansionist campaign to unite "all Serbs in one state".

Aiming to achieve his political objectives Milosevic supported the "gatherings of solidarity", which Kosovo Serbs and Montenegrins organized in cities of Serbia and Montenegro to demonstrate "the truth on Kosovo", that in fact they only promoted the idea to change the Constitution and to establish the power on Serbia on autonomous provinces. Furthermore, additional objective of gatherings was to change the ruling elite in autonomous province of Vojvodina and in republic of Montenegro, respectively their replacement with loyal people to Serbian programme. The fall of Vojvodina leadership in October $1988^{6}$ and later of Montenegrin leadership in January 1989, ${ }^{7}$ provided a possibility to Milosevic to focus his entire energy towards Kosovo, with the aim to abolish its autonomy. The meeting of Kosovo Assembly, held on 23 March 1989, was accompanied by an extraordinary physical and psychological pressure that Serbian political and police circles exercised over the members of Kosovo Assembly. The Kosovo Albanian demonstrations on defence of the Constitution faced a harsh police violence; only during the March 198921 demonstrators were killed, besides many wounded and imprisoned ones. On 23 March 1989, the Assembly of Socialist Autonomous Province of Kosovo, contrary to the will of people and Albanian deputies, amended the Constitution of 1974. As a result the political autonomy of Kosovo within the Yugoslav Federation was abolished. Serbia established control over Kosovo. The final confirmation of constitutional amendments were promulgated through a special session of Serbia Assembly in Belgrade on 28 March 1989. ${ }^{8}$

Serbia established its control over all social-economic-political institutions in Kosovo. Over than 30.000 Albanian employees were fired, ${ }^{9}$ pupils, students and teachers were fired also from their schools and universities.

Disagreeing with the violent changes, the delegates of the Assembly of Kosovo on July 2, 1990 adopted the Constitutional Declaration, which declared Kosovo as an equal unit with other units of the former Yugoslavia. In response the Assembly of Serbia released the Law No. 33/90, and thus banned the work of the Kosovo Assembly and its Executive Council (government), taking over the powers exercised by the institutions of Kosovo. ${ }^{10}$

5 Nevenka Tromp Vrkić, "Kosovo and the Desintegration of Yugoslavia," in Kosovo-Kosova, Confrontation or Coexistence (Nijmegen: Peace Research Centre, 1996), 50.

6 “Gazeta Rilindja,” October 7, 1988, 1.

7 “Gazeta Rilindja,” January 14, 1989, 1.

8 Noel Malcolm, Kosova - Një histori e shkurtër, (Prishtinë: Koha, 2011), 430-31.

9 “Arkivi i Ministrisë së Punëve të Jashtme të Shqipërisë (Further: AMPJ), Fondi: Kosova, Dosja Nr. 1148," 1990, 60 .

10 “Службени Гласник Социјалистичке Републике Србије, Број 33,” 1990, 1225. 
Now, the Kosovo Albanians were put in front of a historical crossroad - to accept tacitly a new reality and to subdue to the Serbian regime, or to pursue an old century old objective for freedom and democracy. This period marked the consolidation of the new political parties, which emerged through the pluralism. Under the leadership of the Kosovo Democratic League, as a biggest and unique political movement of Albanians in Yugoslavia, which gathered all the intelligence, the Kosovo Albanians upgraded their demands. At a meeting held in the city of Kacanik, the Kosovo Assembly deputies promulgated on 7 September 1990 the Constitution of Kosovo, whereas the Referendum on the independence ${ }^{11}$ of September 1991, marked the transformation of Kosovo Albanian claims from a federal unit in Yugoslavia into an independent subject.

Based on the adoption of the above acts, the Kosovo political class worked in two directions: in internal consolidation by building parallel state institutions (they set up an independent education system - homes / schools, health institutions) and started a civil resistance against the ongoing violence, and raising the awareness about the Kosovo issue in the international arena.

The Kosovo Albanian claim for freedom and independence and the stance of the international community towards them, can be summarized in the phases:

The demands of the political leadership of Kosovo Albanians for recognition of the claims for freedom and independence and the attitude of the international community towards them can be summarized in three phases: (1) the stance of the international community during the years 19901992; (2) 1995-1997, and (3) 1998-1999.

\section{The stance of the international community during the years 1990-1992}

The commitment for a right solution of Kosovo issue in a form of an independence was indifferently received not only by the international community, but also by other federal units. The Assembly of the Republic of Albania was the single authority to have recognized the Republic of Kosovo, on 21 October 1991, as a sovereign and independent state, based on freedom and equality with other people in Yugoslavia. ${ }^{12}$

Such an attitude of the international community was an intertwining of complex international political circumstances. The fall of communism and establishment of a new world order, accompanied by dissolution of Yugoslavia, Czechoslovakia and Soviet Union, posed a serious challenge to USA and Europe. The main challenge was to set up the main priorities in foreign policy and stance to be taken towards new developments. The unification of Germany had jeopardized the dominant positions of United Kingdom and of France in Europe. To get its role of an important factor in Europe, Germany welcomed the separation of Slovenia and Croatia, whereas France and United Kingdom didn't support the creation of new states. ${ }^{13}$

Unlike Europe, Yugoslavia was no longer as strategically important to the United States, when it played the role of balancer between East and West, so its dissolution did not affect its interests. But the US presidency was aware of a report compiled in November 1990 by the CIA,

11 Historia e Shqipërisë dhe e shqiptarëve (Prishtinë: Siprint, 2001), 386.

12 “AMPJ, Dosja 1598, Deklaratë e Kuvendit Popullor të Republikës së Shqipërisë," 1991, 141-42.

13 Dejan Maralov, "The Policy of the USA and EU towards the Disintegration of Yugoslavia," International Journal of Social Science Tomorrow Vol 1, no. 2 (2012): 1-3. 
which foresaw ethnic unrest and violence, so to avoid it, the US diplomacy was committed to human rights and economic development in Yugoslavia. ${ }^{14}$

The international community, occupied with the situation described above, which was further exacerbated by the outbreak of the armed conflict in Croatia and Bosnia and Herzegovina, did not pay attention to the claims of Kosovo Albanians. The international community was committed only to the protection of fundamental human rights and freedoms and to the restoration of a local autonomy in Kosovo. Such a stance is proved by the European Parliament resolution, released on 15 February 1990, ${ }^{15}$ as well as by a Resolution adopted by US, which called for the ban of violence, protection of human rights and restoration of Kosovo's political autonomy. ${ }^{16}$

The tendencies of the international community to ignore Kosovo's claim to independence was further reinforced by the lack of competence to analyse the legal and economic consequences deriving from the break-up of Yugoslavia. The European Union therefore set up the Badinter Commission in August 1991 as a mechanism to provide the Peace Conference with legal opinions on Yugoslavia and to facilitate peace talks between constituent subjects of Yugoslavia. Although not binding, these opinions were of specific importance and were reflected in the case of Kosovo, especially those relating to the right of peoples to self-determination and independence. The Opinion No. 2 didn't recognize the right to self-determination of a nation within a republic and required the protection of human and ethnic rights; the Opinion No. 3 warned that the borders between republics should not change. ${ }^{17}$

The Badinter's opinions worsened further the international position of Kosovo, since the Kosovo hadn't been a republic but only a province with certain political autonomy within the former federal Yugoslavia, which has already been forcibly revoked by Serbia. Taking into account Badinter's views, the international community was engaged only in maintaining the peace and tranquillity in Kosovo, aiming to achieve it through the accomplishment of ethnic or minority rights. Based on this stance, numerous proposals were drafted and elaborated at the Hague Conference during 1991, as a wide autonomy for minorities in specific regions. This kind of autonomy included some specific right in the field of education and self-government. ${ }^{18}$

Until the summer of 1992, international actors: the International Conference on the Former Yugoslavia, the European Union, the Organization for Security and Co-operation in Europe (OSCE) and the United Nations paid only minimal attention to Kosovo, if not completely excluded from the process of disintegration of Yugoslavia. But, driven by fears that fighting from Bosnia and Herzegovina may spread to Kosovo, the international actors were content to listen only the views of Kosovo Albanians, but did not allow Kosovo to participate directly in the European Union Conference on Yugoslavia held towards end of August 1992 in London. ${ }^{19}$

14 Dejan Maralov, 9.

15 “AMPJ, Dosja 1098, Rezolutë mbi gjendjen në Kosovë,” 1990, 12-14.

16 “AMPJ, Dosja 957/1, Rezolutë e Senatit Amerikan për Kosovën, 1990, 11-16.

17 Allain Pellet, "The Opinions of the Badinter Arbitration Committee: A Second Breath for the SelfDetermination of Peoples," European Journal of International Law Vol. 3, no. 1 (1992): 179-80.

18 Richard Caplan, "International Diplomacy and the Crisis in Kosovo," International Affairs Vol. 74, no. 4 (1998): 748-49.

19 Raporti Kosovar (Prishtinë: Instituti për kërkime dhe zhvillimeve të politikave, Seria e kërkimeve politike, 2005), 42; 304-5. 
At the above conference, the issue of Kosovo was addressed in the Working Group on Ethnic Communities and Minorities, which was tasked to recommend initiatives to resolve ethnic problems in Yugoslavia. At the proposal of this group it was decided to establish a special body for the former autonomous province of Kosovo. ${ }^{20}$

The establishment of this body was not an urgent matter for the international community, at a time when fighting in Croatia and Bosnia and Herzegovina had already taken on serious proportions.

The standpoint regarding Kosovo embraced a reflection of the claims made by Serbs in Croatia or Bosnia and Herzegovina. The commitment to preserve the territorial integrity of these two republics was also reflected in the case of Serbia. The international community also acted towards preserving the territorial integrity of Serbia, recognizing Kosovo as an integral part of it. The recognition of Serbia's jurisdiction over Kosovo could be proved by statements of some European diplomats. Lord Oven, who replaced Lord Carrington as the head of the Conference on former Yugoslavia, through a press conference held in Prishtina called Serbs and Albanians for: "Serbs should agree about the autonomy for Albanians, and Albanians should recognize Serbia". ${ }^{21}$ The UK Foreign Deputy Minister, Daglas Hog, in the event of inauguration of UK Embassy in Skopje, December 1993, stated: "Kosovo is a part of Serbia. We do not look to ruin the integrity of Serbia. Serbia would be forced to provide some political rights to Kosovo, up to the autonomy". ${ }^{22}$ Italy, Germany and France were also declared for a broad autonomy to Kosovo. Even the administration of Bill Clinton supported the idea for a broad autonomy to Kosovo under the Serbian sovereignty. ${ }^{23}$

So the international factor insisted on maintaining the peace, but on the other hand required to preserve the integrity of Serbia. Two actions were taken to achieve this goal: first, it warned Serbia to renounce violence - on 24 December 1992, President Bush addressed a letter to Slobodan Milosevic, famous as the "Christmas Warning," which stressed that: "In case of conflict in Kosovo caused by Serbian actions, the US will be prepared to use military force against Serbs in Kosovo and Serbia." ${ }^{24}$ Secondly, the international community tried to persuade Kosovo Albanian leaders to reintegrate into Serbia's political system, in the hope that they would change the government and thus gain their rights. Following this goal, the head of Serbian oppositional parties, Milan Panic, met with Ibrahim Rugova in London, and offered the latter the restoration of human rights and autonomy for Kosovo if Albanians were to go to the polls. ${ }^{25}$ However, Kosovo Albanians did not participate in the Serbian elections, since they perceived not belonging to Yugoslavia anymore. In his memoirs, the US ambassador to Belgrade noted the Kosovo Albanian leadership's insistence on not recognizing Serbia's authority. ${ }^{26}$ The Kosovo Albanian leadership made it known to the international community that the Albanians were determined to liberty and sovereignty, and that

20 "The Work Programe of London Conference 1992," accessed December 30, 2020, https://www. peaceagreements.org/masterdocument/1171.

21 Rexhep Qosja, Çështja Shqiptare, Historia dhe Politika (Tiranë: Toena, 1998), 260.

22 Rexhep Qosja, 261.

23 Rexhep Qosja, 261.

24 Tim Judah, Kosovo What Everyone Needs to Know (Oxford University Press, 2008), 71.

25 Bülent Sarper Ağir, “Transformation of K-Albanians' Struggle from Parallelism to Armed Conflict: Why Is Violence Necessary?," The Turkish Yearbook of International Relations Vol. 43 (2012): 112.

26 Warren Zimmerman, Origins of a Catastrophe, with an Updated Preface and Epilogue on Bosnia and Kosovo, 1999, 81. 
there was not turning back. This position laid the groundwork for the claim to independence, to be submitted in completely different circumstances a few years later.

\section{The stance of the international community during the years 1995-1997}

During the years 1992-1995 the international community was mainly engaged to bring an end to fights in Croatia and Bosnia and Herzegovina. The Serbian police violence continued in Kosovo. The Kosovo political elite hoped that the solution for Kosovo issue may be found within the efforts for a peaceful end to the conflict in Bosnia-Herzegovina. Since the European Community was not able to find a solution for Bosnia-Herzegovina, such a responsibility was taken over by United States with the aim to prevent the spread of conflict. The United States organized the Dayton Conference, which was held in November 1995. But Kosovo was not invited to participate in discussions, because the chances for a peace agreement might have been minor in case of broad problem discussion and that participation of Kosovo might have irritate Milosevic, who was seen as a key for a peace. ${ }^{27}$

The failure to elaborate the Kosovo issue in Dayton caused an overall disappointment in Kosovo. Regardless of positive assessments for a peaceful resistance, the West had not rewarded the work of the Kosovo Albanian leader, Ibrahim Rugova. The European Union continued to perceive that improved relations between the EU and the FRY could lead to a "constructive" approach for the FRY to granting some kind of autonomy to Kosovo. ${ }^{28}$

Such a perception means that the European Union had not changed its stance towards Kosovo and was continuing with its old perception - Kosovo in Serbia. An argument that supports this conclusion was the intention of internal community to resolve the issue of education in Kosovo, believing that it may calm the situation and create circumstances for a further dialogue between Serbia and Albanians in Kosovo. ${ }^{29}$ Through the intermediation of the Catholic community Sant'Egidio, Ibrahim Rugova and Slobodan Milosevic signed a document that provided return of students to their facilities, to be starting in September $1996 .{ }^{30}$

Certainly, such an agreement was not implemented, because it had been just a game of Milosevic to remove the pressure of the international community and at the same time to hit the active Albanian resistance that had begun to give the first signs in Kosovo. On the other hand, such an agreement was necessary for Ibrahim Rugova, whose political positions had begun to fade in Kosovo. In these circumstances, the stance of the international community towards Kosovo, made diverse political circles in Kosovo think about finding other forms of national resistance. The analysis of Dayton's decisions led to such a point. Regardless the convictions for ethnical cleansing and genocide, Bosnian Serbs had profited more than they claimed.

By other words, the Dayton agreement made it clear that territorial agreements on ethnic grounds in Balkans enjoyed legitimacy of the West and that claims could be obtained only by use

27 Peter Russell, "The Exclusion of Kosovo from the Dayton Negotiations," Journal of Genocide Research Vol. 11, no. 4 (2009): 12-15.

28 Richard Caplan, "International Diplomacy and the Crisis in Kosovo," 750.

29 Sylë Ukshini, Kosova në politikën e jashtme të BE-së 1991-1997 (Prishtinë: Logos A, 2000$), 150$.

30 Bajram Shatri, Arsimi shqip në Kosovë 1990-1999 (Prishtinë: Libri Shkollor, 2010), 97. 
of force. ${ }^{31}$ In this frame, most of Albanians were convinced that diplomatic and political tools for a peaceful solution have been used, since the international community didn't consider Kosovo as a serious issue. On the other hand, the Serbian violence continued even during the years 19951997, depriving Albanians from their basic rights. The passive resistance movement started its partial transformation. Many people abandoned it and joined to new fractions. In fact, a new active movement accompanied by demonstrations has commenced. The spring event of 1997 in Albania was an additional element that accelerated the active movement. The pyramid schemes, which were allowed by the Albanian Government, had reached their natural end. Albania fell into anarchy. The regime failed to maintain control over the masses, and weapons abandoned by security authorities were stolen. Hundred thousands of weapons were available to citizens, especially automatic rifles. ${ }^{32}$ Thus the organization of an armed resistance was facilitated. Another factor that intensified the transformation of passive resistance into active was the Student Movement, respectively the student demonstrations of October $1997 .{ }^{33}$ The unbridled Serbian police violence against peaceful demonstrators convinced the international community of the difficulties in democratizing Serbia, and it was another turning point, as it turned the West's attention back to Kosovo. The rising interest of European Union and the United States diplomacy confirmed that the international involvement occurs only after the situation had escalated. Internally, demonstrations reassured Albanian masses that an agreement with Serbia was impossible in peaceful conditions, particularly when after the peace in Bosnia, Serbia had free hands to deal with Kosovo; thus Serbia increased the violence and repression in Kosovo. Therefore, in the conditions when the violence and oppression of the Serbian police against innocent civilians was intensified, the patience and status-quo in Kosovo were exhausting. ${ }^{34 *}$

\section{The stance of the international community during the years 1998-1999}

In the conditions of constant Serbian police violence and due to lack of perception to solve the Kosovo issues, the organization of armed resistance was seen as the single alternative for the liberation and the resolution of its issue. Albanians had no choice except to organize an armed resistance for self-defence, to protect their lives, property and to gain a freedom. Although the first steps of the armed resistance organization dates at the beginning of the 1990s, 28 November 1997 marks the public appearance of the Kosovo Liberation Army, in the village of Llaushe of Skenderaj. ${ }^{35}$

Despite the fact that the KLA mission meant fighting for the legitimate right of a nation for freedom, and that Serbian forces had used unprecedented violence against unarmed civilians when fighting with KLA, the international community not only continued to repeat same declarations about the respect of human rights and an autonomy within Serbia, but also described the KLA as

31 Bülent Sarper Ağir, “Transformation of K-Albanians' Struggle from Parallelism to Armed Conflict: Why Is Violence Necessary?," 132.

32 Tim Judah, Kosovo What Everyone Needs to Know, 81.

33 “Gazeta Bujku," October 2, 1997, 1.

34 " In the early 1990 begun the creation of first cells of Kosovo Liberation Army

35 "Kosovo Liberation Army First Public Appearance," accessed October 1, 2020, https://www.youtube. com/watch?v=MiMm5MaaIb8. 
a "terrorist organization". Such a statement by a US diplomat provided to Milosevic a cause to use violence against civilians under the pretext of a "campaign against terrorism", killing many of them. ${ }^{36}$

Despite the consequences, the KLA's persistence and the unreasonable violence perpetrated by the Serbian police against the civilians led the international community to modify its stance towards Kosovo in the first half of 1998. One of the EU representatives had stated that the EU refused to recognize Kosovo as an internal problem of Yugoslavia. ${ }^{37}$ In other words, the armed struggle of the KLA, which was manifested by the sublime act of Jashari family in Prekaz, put Kosovo on the table of discussions; the US administration reconsidered now its previous stance which followed the principle "against the independence, against the Serbian violence". The Kosovo issue was elaborated by different European bodies, who offered various alternatives for resolving the Kosovo issue. One of the key proposals was that of the Contact Group of 9 March 1998, who came up with the proposal for "... a substantial autonomy for Kosovo, which would be expressed through its substantial self-administration, running within Serbia rather than Yugoslavia". Certainly, this paradoxical proposal was unacceptable to Kosovo Albanians.

The rejection of such "autonomies" and the continuation of the armed struggle pushed the international community to advance its proposals for Kosovo. Now, the following proposal was a republic within Yugoslavia. This scheme provided for Kosovo to have its own constitution, to manage its internal affairs, and to have a veto at the federal level. The federal level would have competencies in the areas of defence, financial and foreign policy. The ground of this idea laid on maintenance of international borders of Yugoslavia, although according to principles of Badinter Commission the Republic of Kosovo may be a subject of recognition as a new state. ${ }^{38}$

This scheme was objected by Montenegro, because it diminished its role in the federation. But neither Serbs nor Albanians would accept such a scheme. How could Albanians trust to an army that carried out massacres and incursions, or on the other hand, how could Serbia accept a republic of Kosovo when so much energy and propaganda was spent and when many myths about Serbism had their genesis in Kosovo.

However, during the end of March and throughout April 1998, the US and the European Union, respectively the respective mechanisms under the direction of these entities, came up with different ideas and proposals for resolving the Kosovo issue, starting from a political and administrative autonomy, enlarged, conditional republic, a republic with limited powers, etc. ${ }^{39}$ But, as can be seen, none of these proposals foresaw Kosovo's independence, so all of them, more or less, provided a kind of model through which Kosovo would remain under Serbia, although it was clear that none of these proposals would be accepted by the Kosovo Albanians, because they contradicted the basic principles of liberation war and secession of Kosovo from Serbian rule, thus opening the prospect of its unification with Albania.

36 Richard Caplan, "International Diplomacy and the Crisis in Kosovo," 751-53.

37 "Minorities at Risk Project, Chronology for Kosovo Albanians in Yugoslavia," accessed December 22, 2019, https://www.refworld.org/docid/469f38f5le.html,.

38 Richard Caplan, "International Diplomacy and the Crisis in Kosovo," 757.

39 Shaban Sinani, Kosova në syrin e ciklonit (Tiranë: Dritëro, 1999), 10. 
In addition to the activities of the international community, the KLA was increasingly raising to a factor in the field, and persistently sought to take responsibility for resolving the Kosovo issue. The international community had realized that a solution could not be achieved without the KLA, so to learn the aims of the liberation war from first hand, in the late June 1998 the senior US diplomat, Richard Holbrooke, met KLA representatives in the village Junik. Although Holbrooke stated that "... it was an informal meeting between US and KLA representatives in order to identify the real situation on the ground ..." ${ }^{40}$ such an act could still be considered a tacit recognition of the KLA.

Following the above-mentioned event, the international factor will increasingly be directed to the General Staff of the KLA, as the KLA was a real force on the ground, which could not be ignored by either the international factor or Yugoslavia, in efforts to stop fighting and establish peace. In this way contacts between the KLA and international representatives will be intensified during November 1998. The European and the US diplomats met with KLA representatives in Dragobil in November 1998. ${ }^{41}$ These meetings demonstrated a clear indication that KLA was being considered as a significant factor in the Kosovo issue.

The extension of territories under the KLA control and the Serbian counter-offensive of August 1998, which was accompanied through the displacement of a large number of civilians, prompted the international community's involvement to a ceasefire as a precondition for a peaceful solution. On 13 October 1998 an agreement was signed requiring Serbian police and army to go back to pre-war levels, an OSCE verification mission to be established in Kosovo, and that NATO would bomb Yugoslavia within 96 hours if the agreement fails to be implemented. ${ }^{42}$

But the Serbian violence was going on even during the first quarter of 1999. About 200.000 civilians were displaced, whereas Serbian forces increasingly were moving into Kosovo. The peak of Serbian violence was the Massacre in Recak, 15 January 1999, when 47 civilians were killed. ${ }^{43}$ On 20 March 1999 the Verification Mission left Kosovo.

In meantime, the Rambouillet Conference began its work in February 1999. The main task was to find a peaceful solution for Kosovo. The talks were running on the frames drafted by diplomats Hill and Petrisch. The Kosovo Albanian delegation included representatives of the KLA and the Kosovo political spectrum. The Kosovo delegation was headed by the KLA representative, Hashim Thaqi. The first draft agreement consisted of five points: immediate cessation of violence; immediate withdrawal of Yugoslav police and military forces from Kosovo; the stationing in Kosovo of a NATO-led military force; safe return of refugees and displaced persons; and a political solution consisting of extended autonomy for Kosovo. ${ }^{44}$ But the proposal had not been acceptable

40 “Kosovo: US Envoy Richard Holbrook Meets KLA,” accessed January 2, 2020, https://www.youtube. com/watch? $\mathrm{v}=\mathrm{n}-\mathrm{mb} 4 \mathrm{vX} 2 \mathrm{gUk}$.

41 Jakup Krasniqi, Kthesa e madhe - Ushtria Çlirimtare e Kosovës (Prishtinë: Gjon Buzuku, 2006), 147.

42 Wolfgang Petrisch and Robert Pihler, Rruga e gjatë në Luftë - Kosova dhe bashkësia ndërkombëtare 1989-1999 (Prishtinë: Koha, 2002), 129-30; Tim Judah, Kosova luftë dhe hakmarrje (Prishtinë: Koha, 2002), 231.

43 Kosovo as Seen as Told, An Analyses of Human Rights Finding of the OSCE Kosovo Verification Mission October 1998 to June 1999 (OSCE, 1999).

44 Enika Abazi, "The Role of International Community in Conflict Solution. Which Way Forwards?," Balkanologie Vol 8, no. 1 (2004): 28. 
to both parties. Yugoslavia refused the presence of international forces, and the Albanians the option of a broad autonomy which they already had with the 1974 Constitution. The claim of the Albanian political spectrum was independence, as brutal Serbian violence had historically left no possibilities for Albanians to live under the umbrella of the Serbian state.

The talks which had been interrupted due to disagreements resumed on 15 March 1999. The new text of the negotiations offered an extended autonomy or an internal self-government in the field of education, health and economy. Kosovo would have a president and an assembly, a supreme court, a government, and so on. Foreign troops and officials would guarantee the implementation of the agreement. Extended autonomy would be offered for a period of three years. After three years, an international conference would be held to decide on Kosovo's final status.

However, in essence, Serbia's integrity and sovereignty would be preserved. The competencies of the FRY in Kosovo would be: (a) territorial integrity; (b) the preservation of the common market within the FRY; (c) monetary policy; (d) protection; (e) foreign policy; (f) customs; (g) the federal tax system; etc. Furthermore, Kosovo would have three levels of law enforcement authorities: Kosovan, republican and federal, while borders would be controlled by Yugoslav authorities (approximately 1,500 soldiers). A NATO force would land in Kosovo as a guarantor of the agreement. ${ }^{45}$ In fact, the international offer was nothing more than an autonomy that Kosovo already had with the Constitution of 1974 . However, at the end of the draft text laid a paragraph that provided the organization of an international conference to determine the mechanisms for resolving the final status of Kosovo based on the will of the people, the efforts of the parties to abide by the agreement and the Helsinki Final Act. ${ }^{46}$

Regardless that a conference for the final status of Kosovo was promised, the draft text containing paragraphs about the preservation of territorial integrity of FRY and common policies on the main fields of the state system, was hardly acceptable for Kosovo Albanian delegation. The US State Secretary, Mrs. Madeline Albright, provided clear guarantees to Albanian delegation in Rombouillet that the expression "will of nation" means the will of people living in Kosovo, to be expressed through a referendum. ${ }^{47}$

The Albanian delegation signed the agreement, while the Serbs rejected it. Although the agreement provided for the preservation of Yugoslavia's integrity and the presence of a Yugoslav military force to guard Kosovo's borders, Serbia's refusal could be linked to two factors: the deployment of NATO forces in Kosovo rather than the UN; as well as the free movement of NATO troops throughout Serbia. ${ }^{48}$

Despite the fact that through the Rambouillet Conference the international community consumed the political and diplomatic means to achieve the goal, Belgrade was offered the final

45 "United Nations Security Council, Rambouillet Accords, Interim Agreement for Peace and SelfGovernment in Kosovo" (United Nations), 9-62, accessed January 2, 2020, https://peacemaker.un.org/ sites/peacemaker.un.org/files/990123_RambouilletAccord.pdf,.

46 "United Nations Security Council, Rambouillet Accords, Interim Agreement for Peace and SelfGovernment in Kosovo," 85.

47 Eric Herring, "From Rambouillet to Kosovo Accords: NATO War against Serbia and Its Aftermath," The International Journal of Human Rights Vol. 4:3, no. 4 (2007): 226.

48 Peter Russell, "Humanitarian Intervention in Kosovo: Fact or Fiction," 44. 
opportunity to change its position, before the option of using force remained the single option. US Special Envoy Richard Holbrooke stayed in Belgrade on 22-23 March 1999, to hold intensive talks with Milosevic that lasted not less than 11 hours. At the same time, senior Russian diplomat Primakov, in an attempt to extend Russian influence in the region, tried to persuade US VicePresident Al Gor that "the intervention would cause casualties and undermine relations between Russia and the United States." However, Milosevic had analysed the NATO attacks on Iraq in December 1998, which lasted only two days, and the decision to oppose the agreement was reinforced by the flow of information from a French operative at NATO Headquarters that military intervention would be of limited scale ${ }^{49}$ thus Milosevic's calculations went so far as to hope that a possible resistance to an air strike would significantly strengthen his position, especially when the world political arena was talking about the right to perform the air strike.

Milosevic's refusal to accept the deal put Western allies ahead of an act. Revolted by Milosevic and feared that the conflict would spread and destabilize the region, other factors that influenced NATO intervention were the evolution of the alliance's political goals and its credibility. In these circumstances, NATO faced two other challenges: (1) clear signals from the two members of the United Nations Security Council, Russia and China, that they would veto any request for attacks against a country; and (2) differences between NATO member countries, which mainly concerned the issue of the duration of air strikes, highlighting a sensitive issue for them - ground intervention if air strikes did not bring results. While Britain stressed the need for a strong response, France, Italy and Greece insisted on diplomatic solutions, without the use of force. Germany, whose government consisted of a delicate coalition, found itself in a difficult position especially when the possibility of ground intervention arose. Undoubtedly the U.S. stance was most important, because of their weight within the North Atlantic organization, within the Contact Group, and generally because of their strength and authority in the international arena. The US stated that the bombing was necessary to demonstrate NATO's opposition to Serbian aggression, to prevent further attacks on civilians, and to undermine Serbia's capacity to continue the war. ${ }^{50}$

The NATO airstrike campaign against the Yugoslav military and police targets began on 24 March 1999. The issue of NATO attack legitimacy was raised. The legitimacy of the NATO intervention was logical and the action was based on and justified on two basic interrelated arguments - the doctrine of humanitarian intervention and the implementation of three resolutions adopted by the United Nations Security Council regarding the Federal Republic of Yugoslavia: Resolution 1160 (31 March 1998), Resolution no. 1199 (23 September 1998), and Resolution no. 1203 (October 24, 1998) which were dedicated to stopping the Serbian repression in Kosovo and achieving peaceful solutions. ${ }^{51}$

For 78 days the Yugoslav military and police forces, in particular those deployed in Kosovo, faced NATO air and KLA attacks on the ground. In this way, the KLA became a NATO ally; due to its credibility NATO aimed at victory at all costs, but due to political complications between the

49 John Norris, Collision Course - NATO, Russia, and Kosovo (London: Praeger Publishers, 2005), 1-3.

50 Kaufman, J. P., "NATO and the Former Yugoslavia: Crisis, Conflict and the Atlantic Alliance," Journal of Conflict Studies Vol. 19, no. 2, accessed December 2, 2019, https://journals.lib.unb.ca/index.php/JCS/ article/view/4355.

51 "United Nations Security Council Decisions" (United Nations), accessed December 2, 2020, https:// undocs.org/S/RES/1203(1998). 
allies, avoided official communications with the KLA. In this regard, through uninterrupted field operations, the KLA accelerated the military capitulation of Yugoslavia and the withdrawal of Yugoslav forces from Kosovo. This fact was also confirmed by the statement of the Chief of Staff of the Yugoslav Army in Kosovo, Nebojsa Pavkovic, who stated that ".... if we estimate the losses, then it turns out that the biggest losses we suffered from the KLA than from NATO aviation ...".52

The agreement was signed on 9 June 1999 in Kumanovo by KFOR General Mike Jackson and the Serbian delegation, Svetozar Marjanovic, General of the Yugoslav Army, and General Obrad Stevanovic, representing the Ministry of Interior of the Republic of Serbia, included: the complete withdrawal of Yugoslav-Serbian forces from Kosovo and the dynamics of its implementation, and the installation in Kosovo of an international military and civilian presence under the umbrella of the United Nations. ${ }^{53}$

The predictions of the Kosovo Albanians that with the departure of the Serbian forces, the international community would recognize the right of Kosovo to self-determination, did not come true. At the insistence of the international community, the old and new political forces of Kosovo, which emerged as a result of the transformation of the Kosovo Liberation Army, were forced to agree to the formation of independent institutions of Kosovo under the auspices of the United Nations, a relatively long process that eventually led to the declaration of Kosovo as an independent state on 17 February 2008.

\section{Conclusion}

During the years 1990-1999 the international community generally held a negative attitude towards the claims of Kosovo Albanians for independence. It was focused on human rights and to ensure a kind of autonomy within Serbia and Yugoslavia, respectively. Such stance was more pronounced in 1991-1992 as the focus of the international community was on the problems arising from the break-up of Yugoslavia and on shaping the attitude it had to take.Observing that claims for freedom could only be realized through force, an armed conflict broke out in Kosovo, which was followed by brutal Serbian violence that resulted in a campaign of ethnic cleansing. NATO bombardment aimed stopping the ethnical cleansing; the bombardment ended with withdrawal of Serbian forces from Kosovo.

Even after the departure of the Yugoslav forces, the international community did not automatically recognize the right of the Albanian people to self-determination, nor its armed struggle for freedom and independence. The international community insisted on building new institutions under the control of the United Nations, a long process that eventually resulted in Kosovo being declared an independent and sovereign state on 17 February 2008.

52 "INTERVJU: General Nebojša Pavković - Bili smo spremni da damo život za odbranu Srbije! BalkanInfo," accessed October 20, 2019, https://www.youtube.com/watch?v=dTVFjLg2Zj4.

53 United Nations, "Military Technical Agreeement between the International Security Force (KFOR) and the Government of the Federal Republic of Yugoslavia and the Republic of Serbia," accessed January 2, 2020, https://peacemaker.un.org/sites/peacemaker.un.org/files/990615_ MilitaryTechnicalAgreementKFORYugoslaviaSerbia.pdf. 


\section{Sonuç}

1990-1999 yılları arasında uluslararası güçlerin, Kosovalı Arnavutların bağımsızlık taleplerinde israr ederken, Sırbistan bu talepler karşısında olumsuz bir tavır sergileyereki, bu talepleri dikkate almadı. Bunun yanı sıra Uluslararası güçler Kosova’nın özerkliği ve halkının insan haklarına noktasında çaba göstermiştir. Özellikle 1991-1992 yılları arasında Yugoslavya'nın dağılması sürecinde uluslararası güçler olayları daha yakından takip ederek Kosova'nın yanında olduğu göstermiştir. Özgürlük taleplerinin ancak savaş ile gerçekleştirilebileceğini gören Kosova halkı, bu doğrultuda ilk adımlarını attıktan sonra Sırbistan tarafından etnik temizleme kampanyasıyla sonuçlanan acımasız Sırp şiddeti patlak verdi. Etnik temizliğin ardından NATO bombalaması başladı ve Sırp güçlerinin Kosova'dan çekilmesiyle sona erdi. Bunun ardından uluslararası güçler bir taraftan Arnavut halkının bağımsızlığını tam anlamıyla tanımaz iken, diğer taraftan da özgürlük için silahlı mücadelelerini de tam anlamıla desteklemedi. Uluslararası toplum, Kosova'nın 17 Şubat 2008'de bağımsız ve egemen bir devlet ilan edilmesiyle sonuçlanan uzun bir süreç olan Birleşmiş Milletler'in kontrolü altında yeni kurumlar inşa etmekte ısrar etti.

\section{Bibliography}

\section{Archival sources:}

Arkivi i Ministrisë së Punëve të Jashtme të Shqipërisë, fondet:

- Kosova, dosja nr. 1148, viti 1990;

- Dosja nr. 1098, Rezolutë mbi gjendjen në Kosovë, viti 1990

-Dosja nr. 957/1, Rezolutë e Senatit Amerikan për Kosovën, viti 1990

- Dosja 1598, Deklaratë e Kuvendit Popullor të Republikës së Shqipërisë, viti 1991

Abazi, Enika, "The Role of International Community in Conflict Solution. Which Way Forwards?” Balkanologie Vol 8, no. 1 (2004).

Ağir, BűlentSarper, “Transformation of K-Albanians' Struggle from Parallelism to Armed Conflict: Why Is Violence Necessary?" The Turkish Yearbook of International Relations Vol. 43 (2012).

Biserko, Sonja, Kovanje antijugoslovenske zavere. Vol. Vol. 1. Beograd: Helsinksi odbor za ljudska prava u Srbiji, 2006.

Caplan, Richard, "International Diplomacy and the Crisis in Kosovo." International Affairs Vol. 74, no. 4 (1998).

“Службени Гласник Социјалистичке Републике Србије, Број 33,” 1990.

Herring, Eric, "From Rambouillet to Kosovo Accords: NATO War against Serbia and Its Aftermath.” The International Journal of Human Rights Vol. 4:3, no. 4 (2007).

“Gazeta Bujku,” October 2, 1997.

“Gazeta Rilindja,” October 7, 1988. 
“Gazeta Rilindja,” January 14, 1989.

Historia e Shqipërisë dhe e shqiptarëve. Prishtinë: Siprint, 2001.

Krasniqi, Jakup, Kthesa e madhe - Ushtria Çlirimtare e Kosovës. Prishtinë: GjonBuzuku, 2006.

"INTERVJU: General Nebojša Pavković - Bili smo spremni da damo život za odbranu Srbije! BalkanInfo." Accessed October 20, 2019. https://www.youtube.com/watch?v=dTVFjLg2Zj4.

Judah, Tim, Kosova luftë dhe hakmarrje. Prishtinë: Koha, 2002.

\section{- Kosovo What Everyone Needs to Know. Oxford University Press, 2008.}

Kosovo as Seen as Told, An Analyses of Human Rights Finding of the OSCE Kosovo Verification Mission October 1998 to June 1999. OSCE, 1999.

“Kosovo Liberation Army - First Public Appearance.” Accessed October 1, 2020.

https://www.youtube.com/watch?v=MiMm5MaaIb8.

Kosovo: Pravo i Politika, Kosovo u Normativnim Aktima Pre i Posle 1974. Godine. Beograd: Helsinki odbor za ljudska prava u Srbiji, 1998.

"Kosovo: US Envoy Richard Holbrook Meets KLA.” Accessed January 2, 2020. https:// www.youtube.com/watch? $=\mathrm{n}-\mathrm{mb} 4 \mathrm{vX} 2 \mathrm{gUk}$.

Malcolm, Noel, Kosova - një histori e shkurtër,.Prishtinë: Koha, 2011.

Maralov, Dejan, "The Policy of the USA and EU towards the Disintegration of Yugoslavia." International Journal of Social Science Tomorrow Vol 1, no. 2 (2012).

Meier, Viktor, Fundi i Jugosllavisë. Lubjanë: Liria, 2007.

Mihailović, Kosta and Krstić, Vasilije, Memorandum of the Serbian Academy of Sciences and Arts - Answers to Criticism. Belgrade: Serbian Academy of Sciences and Arts, 1995.

"Minorities at Risk Project, Chronology for Kosovo Albanians in Yugoslavia." Accessed December 22, 2019. https://www.refworld.org/docid/469f38f51e.html

Norris, John, Collision Course - NATO, Russia, and Kosovo. London: Praeger Publishers, 2005.

P. J, Kaufman, "NATO and the Former Yugoslavia: Crisis, Conflict and the Atlantic Alliance.” Journal of Conflict Studies Vol. 19, no. 2. Accessed December 2, 2019. https://journals. lib.unb.ca/index.php/JCS/article/view/4355.

Pellet, Allain "The Opinions of the Badinter Arbitration Committee: A Second Breath for the Self-Determination of Peoples.” European Journal of International Law Vol. 3, no. 1 (1992).

Petrisch, Wolfgang and Pihler, Robet, Rruga e gjatë në luftë - Kosova dhe bashkësia ndërkombëtare 1989-1999. Prishtinë: Koha, 2002.

Qosja, Rexhep, Çështja shqiptare, historia dhe politika. Tiranë: Toena, 1998.

Raporti Kosovar. Prishtinë: Instituti për kërkime dhe zhvillimeve të politikave, Seria e 
kërkimevepolitike, 2005.

Russell, Peter, "Humanitarian Intervention in Kosovo: Fact or Fiction." Dublin Eurepean Institute, 2004.

_. "The Exclusion of Kosovo from the Dayton Negotiations." Journal of Genocide Research Vol. 11, no. 4 (2009).

Sinani, Shaban, Kosova në syrin e ciklonit. Tiranë: Dritëro, 1999.

Shatri, Bajram. Arsimi shqip në Kosovë 1990-1999. Prishtinë: LibriShkollor, 2010.

“The Work Programe of London Conference 1992.” Accessed December 30, 2020. https:// www.peaceagreements.org/masterdocument/1171.

Ukshini, Sylë, Kosova në politikën e jashtme të BE-së 1991-1997. Prishtinë: Logos A, 2000.

United Nations. "Military Technical Agreeement between the International Security Force (KFOR) and the Government of the Federal Republic of Yugoslavia and the Republic of Serbia." Accessed January 2, 2020.

https://peacemaker.un.org/sites/peacemaker.un.org/files/990615 MilitaryTechnicalAgreementKFORYugoslaviaSerbia.pdf.

"United Nations Security Council Decisions." United Nations. Accessed December 2, 2020. https://undocs.org/S/RES/1203(1998).

"United Nations Security Council, Rambouillet Accords, Interim Agreement for Peace and Self-Government in Kosovo." United Nations. Accessed January 2, 2020. https://peacemaker. un.org/sites/peacemaker.un.org/files/990123_RambouilletAccord.pdf

Vrkić, Nevenka Tromp, "Kosovo and the Desintegration of Yugoslavia." In Kosovo-Kosova, Confrontation or Coexistence. Nijmegen: Peace Research Centre, 1996.

Vujačić, Veljko "Serbian Nationalism, Slobodan Milosević and the Origins of the Yugoslav War," The Harriman Review, Vol. 8, no. 4 (1995).

Zimmerman, Warren, Origins of a Catastrophe, with an Updated Preface and Epilogue on Bosnia and Kosovo, 1999. 